\title{
Katie Mitchell and the Technologies of the Realist Theatre
}

\section{Tom Cornford}

To cite this article: Tom Cornford (2020) Katie Mitchell and the Technologies of the Realist Theatre, Contemporary Theatre Review, 30:2, 168-192, DOI: 10.1080/10486801.2020.1732953

To link to this article: https://doi.org/10.1080/10486801.2020.1732953

曲 Published online: 10 Jun 2020.

Submit your article to this journal 준

Џ Article views: 53

Q View related articles ¿

View Crossmark data 


\section{Katie Mitchell and the Technologies of the Realist Theatre}

\section{Tom Cornford}

1. Siobhan Davies and

Katie Mitchell,

'Conversations

Around

Choreography', https://www.siobhan davies.com/conversa tions/mitchell/tran script.php (accessed December 10, 2019).

2. Ibid.

3. Katie Mitchell, The Director's Craft (Abingdon: Routledge, 2009), 1.

4. Konstantin Stanislavsky, ed. and trans. Jean Benedetti, My Life in Art (Abingdon: Routledge, 2008), 257.

5. Mitchell, The Director's Craft, 230.

6. 'Woman Alone: Directing Opera', Interview with Elaine Kidd, Video, https:// podcasts.ox.ac.uk/ woman-alonedirecting-opera (accessed April 23, 2019), 00:13:50, $00: 14: 37$.
Katie Mitchell is deeply committed not only to the craft of directing, but to the idea that directing is a craft. In 2009, she published The Director's Craft, whose subject is the former, and whose implicit argument is the latter. Speaking to the choreographer Siobhan Davies that year, she exasperatedly recalled an advert for 'a workshop on "blocking" ("the process of organizing the actors on stage') held by a theatre for training directors:

They were advertising it as if that was $90 \%$ of a director's job, and I thought 'Blimey if it were that easy!' What a director is actually trying to do is to help actors to replicate life-like behaviour on stage and this is an enormously complicated task - it's a life's work to be able to learn how to do it accurately. ${ }^{1}$

Mitchell's favoured description of this 'life's work' is of 'a subtle and complex craft', a 'process of making', as she describes it in her book, requiring 'tools', 'skills' and 'training'. 3 The core of this craft, for Mitchell, is the 'system' developed by Konstantin Stanislavsky as 'a technical way to establish the creative state'. ${ }^{4}$ Mitchell first encountered Stanislavsky's system by travelling, in 1989, to Russia and eastern Europe to study the work of directors, and subsequently through studying with the actress Tatiana Olear and director Elen Bowman. ${ }^{5}$ She describes these experiences as 'my real training' and the 'source' of 'everything I do in theatre and opera'. ${ }^{6}$

Mitchell's account of craft rests upon an assumption about what is self-evident in its nature, which is by no means peculiar to her: namely that the techniques that comprise a 'process of making' are ideologically neutral, and proficiency in them is fundamentally a matter of improved accuracy. This is the position from which Mitchell begins her book: 
7. Mitchell, The Director's Craft, 1.

8. Martin Heidegger, trans. William Lovatt, The Question Concerning Technology and Other Essays (New York and London: Garland Publishing, 1977), 13. I am grateful to Donato Wharton for numerous conversations about the technological apparatus of Mitchell's theatre, and for suggesting Heidegger's ideas in response to an early draft of this essay.

9. Heidegger, The Question Concerning Technology, 6.
Early attempts at directing can flounder because directors do not have certain simple tools. Without these tools, directing becomes a process based on chance rather than skill. The tools in this book will help you to make work that is closer to what you want to see - or what you have imagined in your head. It will also encourage you to think about directing as a craft, with skills that can be learnt and built up over time. ${ }^{7}$

Here, 'craft' is understood as a form of technē, the combination of knowledge and activity whereby things are made, which Mitchell exemplifies in instrumental terms by the skilled use of tools. Her first verb, however, gestures towards a more fundamental conception of technē that is suppressed by her account: without 'simple tools', 'attempts at directing' may 'flounder', she writes; not - as we might expect - 'founder' (collapse or fall apart), but flap helplessly or struggle, like a fish out of water. Technē may involve the skilled use of tools, but this does not capture its essential character. More fundamentally, it is a question of being a fish in water, of being well-fitted to the entire condition of one's activity. For this reason, in his famous essay The Question Concerning Technology, the philosopher Martin Heidegger observes that '[f]rom earliest times until Plato the word techne is linked with the word epistemē. Both words are names for knowing in the widest sense. They mean to be entirely at home in something, to understand and be expert in it'. ${ }^{8}$ The director's craft is not simply a matter of proficiency in - for example - the 'tools' of Stanislavsky's system, but a broader and more fundamental capacity to be 'entirely at home in' the theatre's 'mode of revealing', which is to say in its technology.

In search of the essential character of technology, Heidegger observes that the ends and means that it brings into relation with each other make it a causal phenomenon, and he therefore returns to Aristotle's 'four causes' in order to enquire into its nature. He illuminates the four causes with the example of a chalice made by a silversmith:

(1) the causa materialis, the material, the matter out of which, for example, a silver chalice is made; (2) the causa formalis, the form, the shape into which the material enters; (3) the causa finalis, the end, for example, the sacrificial rite in relation to which the chalice required is determined as to its form and matter; (4) the causa efficiens, which brings about the effect that is the finished, actual chalice, $[\ldots]{ }^{9}$

Heidegger argues that 'for a long time, we have been accustomed to representing cause as that which brings something about', in other words, we have assumed that the cause of the chalice is the 'causa efficiens', the craft of the silversmith. This is Mitchell's assumption too, when she asserts that the craft handed down to her from Stanislavsky is the basis of 'everything I do'. Heidegger proposes, however, that we take a broader view of causality and consider, instead, that ' $\mathrm{t}]$ he four causes are the ways, all belonging at once to each other, of being responsible for something else'. Thus, the silver is responsible, in its material properties, for the chalice; likewise, the formal idea of 'chalice-ness' is responsible for each particular chalice, as is the purpose 
10. Ibid., 12 .

11. 'Katie Mitchell on Theatre Directing', 00:06:09.

12. Mitchell, The Director's Craft, 50.

13. Ric Knowles, Reading the Material Theatre (Cambridge: Cambridge University Press, 2004), 32, emphasis in original. for which the chalice is created, as are the techniques by which the chalice is brought into existence. Heidegger argues, therefore, that 'the silversmith is not a causa efficiens', but a means of encompassing these four causes in the process of 'bringing-forth'. This 'bringing-forth' provides Heidegger with a conception of technology that exceeds the merely instrumental:

[E]very bringing-forth is grounded in revealing. Bringing-forth, indeed, gathers within itself the four modes of occasioning - causality - and rules them throughout. Within its domain belong end and means, belongs instrumentality. Instrumentality is considered to be the fundamental characteristic of technology. If we inquire, step by step, into what technology, represented as means, actually is, then we shall arrive at revealing. ${ }^{10}$

For Heidegger, 'revealing' is related to the ancient Greek concept of aletheia, referring to truth in the sense of what is disclosed, or brought out of concealment. Framing the technologies of the realist theatre as overlapping means of revealing exposes the extent to which the director, like Heidegger's silversmith, must manage these multiple ways of being responsible for the revealing work at the heart of a production - or, in other words, for what the production reveals of itself through its performance.

Introducing the MA in Theatre Directing she initiated at Royal Holloway, University of London in 2017, Mitchell proposed that directors need to be skilled in 'nine key areas' (performers, text, design, movement, lighting, sound, music, video, creative team). ${ }^{11}$ The last of these personifies a part of the theatre's 'causa efficiens' - the techniques upon which its productions rely. The preceding eight areas constitute an account of theatre's 'causa materialis', though notably one that leaves out material conditions, such as a theatre's architecture and the constitution of its audiences, that are not easily controlled by the director of a single production. Theatre's 'causa formalis', the 'genre or style of the play' in Mitchell's terms, is more susceptible to directorial control, though - as she observes - '[e]ach genre [...] has its own history and its own logic', which cannot simply be disregarded or altered at will. ${ }^{12}$ This is not exactly the same as the 'causa finalis', the purpose for which a production is created, which is shaped by the wider social and political context of the theatre's operation and artistic policies. In his materialist account of the work of theatre making, Ric Knowles makes tacit reference to the 'causa finalis' by arguing that

[w] hatever the nature, content, or conscious theme of the production, as product, and as the record of a particular ideologically coded process, its central and essentially capitalist message is inscribed, virtually by necessity, within the system itself, and as such it tends to be overwhelmingly culturally affirmative. ${ }^{13}$

For Knowles, then, under capitalism all causes are subordinated, if not quite to the final cause of profit generation, then certainly to the creation 
14. Maddy Costa with Katie Mitchell and Alice Birch, 'Alternative Point of View: The Malady of Death', http://blog. barbican.org.uk/ 2018/05/alternativepoint-of-view-themalady-of-death/ (accessed April 30, 2019).

15. 'Woman. Alone: Directing Opera', 00:31:37.

16. Ibid., 00:27:28.

17. Ibid., 00:31:33.

18. The interest in 'offstage' spaces in these stagings and their simultaneous presentation of different spaces echoes the concerns of Ophelias Zimmer (Berlin, Schaubühne and Royal Court, 2016) and Anatomy of a Suicide (Royal Court, 2017), both of which are discussed elsewhere in this issue by Benjamin Fowler and Anna Harpin. of a cultural space in which the generating of profit is ceaselessly legitimated.

Mitchell has, by contrast, increasingly sought to subordinate all causes within her work to politically critical and resistant ends. She has begun to make what she describes as political interventions by working 'with writers to create an alternative body of theatre texts that "recognise the validity of [patriarchal] oppression"'. ${ }^{14}$ Her creation of this 'alternative body of $[. .$. texts' has depended, as Mitchell has consistently emphasised, on her craft, and therefore on an instrumental account of technē. Mitchell's own account of the reality of her working process, however, gives us cause to question the basis for such an account. She recalls that directing her first opera, Mozart's Don Giovanni (Welsh National Opera, 1996), exposed her, uncomfortably, to the rigid hierarchies and rigidly conventional acting of opera production, as well as to its 'patriarchal structures'. ${ }^{15}$ Returning to WNO two years later to direct Janáček's Jenůfa, Mitchell describes starting 'to shape a very different working practice' that allowed her to negotiate between the demands of the form and her aesthetic preferences and political perspective. ${ }^{16}$ She acknowledges, however, that the systems of opera production had likewise altered her: 'I became more confident with the rehearsal room and dealing with its patriarchal structures, although I noticed that having to deal with these issues and these structures hardened me [...]. I became more adversarial'. ${ }^{17}$ Thus, an instrumental account of technē becomes complicated by the process of becoming accommodated to the larger technological configuration within which the director operates. Heidegger's conception of technology therefore offers a way of seeing the tensions between the 'ideologically-coded process' of generating cultural affirmation described by Knowles and Mitchell's project of generating alternatives to it, because it situates 'the director's craft' within the wider nexus of forces and material conditions with and within which it cannot help but operate.

This article explores Mitchell's work in relation to the nexus of forces and conditions represented by the technological configuration of the realist theatre by concentrating on three of the representational strategies developed by Mitchell within it. The first is 'split-screen staging', using box sets, as in, for example, Mitchell's National Theatre (NT) production of $A$ Woman Killed with Kindness (2011) and her Royal Opera House (ROH) Lucia di Lammermoor (2016). ${ }^{18}$ The second strategy is Mitchell's reshaping of texts so that they cohere when viewed through the narrow aperture of a single subject's viewpoint as in, for example, her productions of Caryl Churchill's version of Strindberg's A Dream Play (NT, 2005), and Sarah Kane's Cleansed (NT, 2016) and 4.48 Psychosis (Hamburg, Deutsches Schauspielhaus, 2017). Finally, I turn to the strategy of 'live cinema' developed in numerous theatre and opera productions since Waves (NT, 2006), in which the on-stage action creates a film which is projected onto a screen above. These strategies - characterised by boxes, apertures, and screens - are derived from the technologies of realism, such as the camera obscura (a box containing a screen onto which an image is projected using a small aperture that may be fitted with a lens), the proscenium arch stage (in German, the Guckkastenbühne, literally the 'looking-box-stage'), and 
19. Mitchell, The Director's Craft, 50.

20. Knowles, Reading the Material Theatre, 25.

21. Simon Shepherd, Direction (Basingstoke: Palgrave, 2012), 84-6.

22. Ibid., 198. both still and cinema cameras. All of these technologies are characteristically modern, in Heidegger's terms, because they 'enframe' the real, making its 'being' available as what he calls 'standing-reserve', a resource to be exploited. This process is - he argues - the essence of modern technology, and 'enframing' is, of course, endemic to the intersecting political oppressions of modernity. White supremacist, capitalist patriarchy - to borrow bell hooks' famous phrase - is predicated upon the enframing of women, of people of colour, and indeed of the natural world, and thereby their conversion to 'standing-reserve'. It is therefore a structural irony of Mitchell's project that the technological configuration with, within which and through which she must work is structurally opposed to her espoused political project of exposing, critiquing, and generating alternatives to patriarchal oppression and ecological crisis.

This essay begins its exploration of the structural tensions between Mitchell's project and the technologies of realism with a short analysis of her production of The Seagull (NT, 2006) and its simultaneous commitment to read Chekhov's play from a feminist position and to communicate that reading with the technologies of the realist theatre (albeit a realism with symbolist overtones, as Mitchell has observed). ${ }^{19}$ In this analysis and those that follow it, I ask both how Mitchell seeks to use the technologies of the realist stage to expose and critique oppression and how those technologies constrain her capacity to resist or present alternatives to hegemony. Although Mitchell's aesthetic strategies are in many ways peculiar to her, this analysis illuminates two wider points of significance. First, it demonstrates some specific mechanisms by which ideology is encoded in theatrical technologies. Second, it exposes the extent to which Mitchell's position exemplifies that of any would-be politically engaged director in the early twenty-first-century theatre. My argument, simply put, is that the technological apparatus of the realist stage is systemically resistant to both critical political analysis and radical political action, and that a director such as Mitchell can therefore only work against wider political systems of domination and exploitation by working within just such a system. In order to sustain a critical political position, therefore, they can only constantly work to expose their own complicity with the object of their critique and thus against their own interests, an undertaking which - as my analysis here will show - cannot help but frequently fail.

\section{Technologies of Realist Organisation: The Seagull (2006)}

Echoing Knowles' description of directors occupying the position of 'middle management', ${ }^{20}$ Simon Shepherd proposes that we consider theatre directing as a branch of 'scientific management', the industrial process popularised in the 1920s whereby labour was analysed, planned, and controlled by a new 'Professional-Managerial Class'. ${ }^{21}$ He therefore suggests that directing may be, essentially, an 'organisational activity'. ${ }^{22}$ In Heideggerian terms, scientific management is 'a mode of ordering' whereby social relations are 'enframed' and thus converted to 'standing- 
23. Prompt Script, National Theatre Archive, 17.

24. Mitchell, The Director's Craft, 28.

25. Ibid.

26. Ibid., 38,74 . reserve' and made available to be exploited as human resources. If the work of directing is characterised by organisation - of ideas, materials, and people's labour - then everything in the director's theatre is a resource, made available to the function of ordering. Shepherd's conception of directing as organisation is particularly apt since it encompasses both interpretive and productive activities: the director organises ideas in their interpretation of a play-text, and then organises labour and other resources according to the pattern they have produced. By grouping these two processes under the heading of organisation, they can be seen to pull in the same direction. However, if we consider that the first activity is fundamentally ideological and the second technological, we can begin to see the ways in which they may also pull apart.

A moment from Mitchell's 2006 production of The Seagull illustrates the point. Hattie Morahan's Nina and Juliet Stephenson's Arkadina meet suddenly, when Nina returns after Konstantin's play has been abandoned. Stephenson is slightly stage left of centre facing Morahan who has emerged from off stage left. Both are blonde and dressed in black. They seem momentarily to be looking both at each other and into a mirror at a version of themselves, an experience to which Stephenson's Arkadina responds by telling Morahan's Nina that 'the way you look that gorgeous voice - it's criminal to be stuck out here in the country. You have real talent. I'm serious. You owe it to yourself to act', and which Nina acknowledges in her response: 'That's my dream. But it will never happen'. ${ }^{23}$ Mitchell's account of the biography of Chekhov's Arkadina offers an illuminating context for this meeting. Mitchell has Arkadina running away at the age of 17 with the 45 year-old 'wellknown actor' Gavril Treplev, marrying him and giving birth to their son, Konstantin, the following year, as a result of which 'her family disinherits her'. ${ }^{24}$ Arkadina then begins to take on 'minor roles' as an actress before, four years later, Treplev dies, 'leaving her with nothing' and a four year-old child. ${ }^{25}$ This biography closely resembles Nina's journey through the play. She is desperate to become an actress, has already run away from home (albeit only for an evening) in order to perform in Konstantin's play, and has, in Mitchell's account, a 'Trigorin scrapbook' in which she pastes stories by Arkadina's partner, the famous, middleaged writer with whom she will later have an affair and produce a child, who will die before the play is over. ${ }^{26}$ Responding to this shared pattern, Mitchell's staging reverberated with recognition: the aspirant actress and avid reader of Trigorin recognised the woman she wanted to become; the middle-aged, metropolitan actress recognised the naïve, provincial young woman she once was, and the audience was invited to recognise the intergenerational repetition of a pattern of patriarchal oppression. Thus, a minor event in the play was organised so as to expose a pattern that is fundamentally ideological.

Mitchell's ordering of Chekhov's play into this pattern was achieved, however, by a process of technological enframing. The mirror-effect was strengthened by the passing resemblance of the actresses Juliet Stephenson and Hattie Morahan, and was therefore, in part, a result of the casting process, in which Mitchell advises the director to consider 
27. Ibid., 102.

28. Ibid., 180.

29. Tom Cornford, 'Love Will Tear Us Apart (Again): Katie Mitchell directs Genet's The Maids', European Stages, http://european stages.org/2017/10/ 28/love-will-tear-usapart-again-katiemitchell-directsgenets-the-maids/?for mat $=$ pdf $($ accessed April 30, 2019).

30. Mitchell, The Director's Craft, 79.

31. Benjamin Fowler, 'The Meaning of Peeling Paint (Notes on a Mitchell Miseen-Scène)', in this issue, 151- 67 (152). 'how casting the actor might work in relationship to other casting decisions'. ${ }^{27}$ It was also highlighted, as I have already observed, by costuming and staging. The characters encountered each other in prominent positions, in a lateral relationship to the stage's frame that was approximately determined by the 'golden ratio' of 1:1.618. Arkadina was in this position relative to the proscenium as a whole, and Nina likewise between Arkadina and the proscenium's stage left side. Mitchell advises directors to '[s]tudy the work of painters', ${ }^{28}$ and I have observed elsewhere that she is a peculiarly painterly director, conforming almost invariably to the proportions of the golden section, which results in a paradoxical feeling of dynamic stasis in her work: '[ $\mathrm{t}]$ he lack of symmetrical balance makes her staging visually dynamic, yet the constant attention to proportional relations [...] gives it a somewhat schematic quality, with each successive moment constituting a static image'. ${ }^{29}$ This feeling of dynamic stasis is characteristic of realism because it is both apparently spontaneous (and thus dynamic) and evidently constructed (and thus static), organising what Mitchell calls 'ingredients from real life' in the proportions - to extend her implicit analogy - of a recipe: 1 part to 1.618, for example. Those proportions relate the action to the frame of the proscenium arch. Thus, realism arranges reality for an aperture. It enframes.

The architectural expression of this tension between dynamic spontaneity and static proportionality is the room, a spatial container of action, arranged so as to organise its possibilities. As Mitchell puts it, 'decisions about the set and furniture are also the first steps that the director makes towards arranging the actors'. ${ }^{30}$ It is no surprise, then, that Mitchell's productions can be considered as a series of rooms. Mitchell has, for example, twice directed Genet's The Maids (Young Vic, 1999 and Stadsschouwburg Amsterdam, 2016), a play that hinges on obsessive attention to the details of a room's arrangement. She has also consistently relocated Chekhov's exterior scenes indoors, including Act 4 of Three Sisters (NT, 2003), Act 2 of The Cherry Orchard (Young Vic, 2014), and Act 2 of this Seagull. Many of Mitchell's rooms, as Benjamin Fowler notes elsewhere in this issue, 'express [her] idiosyncratic taste for rotting buildings or cracked plaster', but there are also contemporary spaces such as hotel rooms (Wastwater, Royal Court 2011 and La Maladie de la Mort, Théâtre des Bouffes du Nord, 2018), garages (Wastwater and When We Have Sufficiently Tortured Each Other, NT 2019), a school hall (St Matthew Passion, Glyndebourne 2007), and an archive above the medieval rooms whose traces it contains (Written on Skin, Festival d'Aix-en-Provence, 2012). ${ }^{31}$ Mitchell's rooms commonly spatialize the central concerns of a production. The royal bedroom in Lessons in Love and Violence (ROH, 2018), for example, was presided over by lanyard-wearing functionaries, who controlled access to the space and served constantly to underline the public consequences of the private events it housed. By contrast, in Ed Hime and Lucy Kirkwood's Small Hours (Hampstead Theatre, 2011) - which was 'entirely inspired by a request' from Mitchell, the audience were marooned alongside Sandy McDade's unnamed woman in the nondescript 
32. Lucy Kirkwood, Plays: One (London: Nick Hern Books, 2016), 'Introduction'.

33. 'Stage Manager's Cue Sheet', held in the National Theatre Archive, indicates a five minute improvisation in the 'DINING ROOM' beginning 'ONCE ALL CAST ARRIVED AT BEGINNERS' and then 'MOVING OFF TOWARDS LIVING ROOM' (situated in 'SL side dock') before clearance was given for the performance to start. There are also notes indicating sound cues for offstage microphones during the performance.

34. John Berger, ed. Geoff Dyer, Understanding a Photograph (London: Penguin, 2013), 90. living room of a north London flat on the night she kills the baby that she refers to as 'it'. ${ }^{32}$ The room's isolation and anonymity communicated her mental state with far greater eloquence than the character could muster in her brief telephone conversations with her partner (who is away working in Manchester) and her mother in Scotland. Likewise, in this Seagull, it was not only the parlous condition of Sorin's estate that was writ large in Vicki Mortimer's design. The emotional lives of the characters were also laid bare by their surroundings: by Act 4, they shuffled and shivered in huge, dilapidated rooms whose windows rattled in the wind.

This relationship between rooms, behaviour and the characters' inner lives extended, in The Seagull, off the stage into spaces that were invisible but audible to the audience. Here, the actors improvised, for example, the action that implicitly precedes Act 1, and the off-stage action during Konstantin and Nina's conversation in Act 4. ${ }^{33}$ The Stanislavskian logic for this practice is that it supports acting: actors will enter much more convincingly as though they have already been talking, it proposes, if they have, indeed, already been talking. Its implementation, however, requires the stage management of simultaneous, parallel action in separate spaces, and thus enframes even that which is beyond the frame of the proscenium arch, making it, likewise, a standing-reserve under directorial/technological ordering.

The following three sections take the three key elements of this analysis of The Seagull one by one. First, I consider the function of boxes in Mitchell's anti-patriarchal stagings of $A$ Woman Killed with Kindness and Lucia di Lammermoor. Second, I consider the aperture and its opening and closure, an image with which Mitchell regularly begins and ends her productions, pairing their visual framing with an effect of temporal slicing that, as John Berger writes of a photograph, 'cuts across time and discloses a cross-section of the event or events that were developing at that instant'. ${ }^{34}$ I use this image to analyse Mitchell's dramaturgical framing of A Dream Play and 4.48 Psychose, both of which focused on a central character, whose isolation from quotidian time discloses a cross-section of it. Finally, I turn to the machinic organisation of human labour to create a seamless flow of screen imagery in Mitchell's numerous 'live cinema' productions. All of these cases serve to draw out specific points of tension which, I argue, are inherent to the project of a politically critical realism, of which Mitchell is currently one of the world's leading exponents.

\section{Boxed In: Patriarchal Confinement in A Woman Killed with Kindness (2011) and Lucia Di Lammermoor (2016)}

Mitchell has described the technique of placing two locations side-byside on stage as a 'split-screen' approach to staging, emphasizing the capacity of its juxtaposition of images to expose and critique the systemic nature of patriarchal oppression. The technology with which Mitchell is able to achieve these stagings is, however, not a screen, but a box. The 
35. Dennis Kennedy (ed.), The Oxford Encyclopedia of Theatre and Performance (Oxford: Oxford University Press, 2003), entry for 'Box Set'. I am grateful to Gilli BushBailey for a crash course in the history of the box set.

36. David Belasco, 'Creating Atmosphere' in Directors on Directing: A Source Book of the Modern Theater, ed. Toby Cole and Helen Krich Chinoy (Indianapolis: BobbsMerrill, 1976), 125-37 (133).

37. 'Immersive Worlds: Designing Katie Mitchell's Theatre', Alex Eales in conversation with Benjamin Fowler in The Theatre of Katie Mitchell, ed. Benjamin Fowler, (Abingdon: Routledge, 2019), 12-38 (22-3).

38. Ibid., 25 .

39. David Hockney, Secret Knowledge:

Rediscovering the Lost Techniques of the Old Masters (New York: Penguin, 2006), 13.

40. Ibid., 124 . three-sided box set, its absent front wall aligned with the proscenium, was '[d]eveloped in Paris', according to Jacky Bratton, 'for melodrama and boulevard farce between 1800 and 1820', and introduced to England by the theatre manager Eliza Vestris at London's Olympic Theatre in $1832 .^{35}$ Bratton notes that, by the turn of the twentieth century, the box set had become the preferred means of changing scenery, its realism also becoming gradually more developed by Broadway producers such as David Belasco.

Belasco seems to have favoured the box set for two principle reasons. First, a box set can be trucked in and out of position on stage in its entirety, enabling an entire scene to be shifted in one movement. Second, it enables a level of realism that flats and other scenic technologies cannot achieve. In the case of Belasco's production of Eugene Walter's The Easiest Way (1909), he even claimed to have 'bought the entire interior' of a 'dilapidated' room in 'the meanest theatrical lodging house I could find' because his workshops 'could not make it look shabby enough'. ${ }^{36}$ This interior was then installed, wallpaper and all, in the three-sided room of a box set, whose windows, doorways and walls could be used by Belasco's stage electricians to produce realistic lighting effects, such as the 'delicate hues of a sunset'. Thus, the real was enframed. Alex Eales, who designs regularly for Mitchell, echoes Belasco's obsession with detail: 'my approach is slightly to overwhelm the audience with information. [...] The more detail, the more bits and pieces you include, it actually becomes more believable as a result'. ${ }^{37}$ Eales refers, likewise, to realist design as a process of 'build[ing] up [...] layers of naturalism', partly with visual details and objects, but also, for example, with 'practical lights' included in the design and 'realistic apertures' for 'naturalistic daylight or moonlight' to come through. ${ }^{38}$

The capacity of the box set to control lighting offers a clue to the origins of this piece of nineteenth-century stage technology, which evolved from the camera obscura, literally a 'dark room' into which an optical image can be projected either through a small hole, a lens or by using a curved mirror. According to the evidence uncovered by the artist David Hockney, mirrors and lenses were commonly used to make paintings in this way from the 1430s. ${ }^{39}$ These projected images are made much clearer by high contrast, which is achieved by lighting them strongly from a particular angle, an effect whose widespread use Hockney attributes particularly to the work of Caravaggio: 'I think of him as like a film director, lighting, costumes, gestures - all would have been carefully staged'. ${ }^{40}$ Hockney and art historian Philip Steadman have revealed numerous techniques for 'using the camera as an aid to composition' in this way, such as Steadman's account of the creative process of the seventeenth-century Dutch painter Vermeer, based upon a mathematical reconstruction of his studio from the evidence of his paintings:

Vermeer could have provisionally chosen his viewpoint, positioned his camera, and roughly arranged the furniture and sitters. He could then 
41. Philip Steadman, Vermeer's Camera: Uncovering the Truth Behind the Masterpieces (Oxford University Press, 2001), 143.

42. Ibid., 157, emphasis in original.

43. Mitchell, The Director's Craft, 79

44. This was Mitchell's second production of the play, which she previously directed in 1991 for the RSC.

45. Royal Opera House, 'Lucia di Lammermoor Insight', YouTubeVideo, March 10, 2016 https://www. youtube.com/watch? $\mathrm{v}=76726 \_$eeV0 (accessed April 30, 2019), 01:03:24.

46. Ibid., 01:15:15. have embarked on a prolonged process of making adjustments, $[\ldots]-$ all the time returning to the camera $[\ldots]-$ until he was finally satisfied. ${ }^{41}$

Steadman argues on the basis of his reconstruction of this process that painting with optics is 'not instantaneous but protracted', and that the function of the camera obscura is that it 'collapses three-dimensional space onto the two-dimensional plane', so that a painting's component parts become 'shapes', which 'can then be studied in compositional terms, and can be manipulated by moving the objects themselves'. ${ }^{42}$ Rather than enabling an artist to capture a 'snapshot' of reality, the camera obscura functioned in painting, therefore, as a device for enframing, for capturing the real and re-presenting it as a series of carefully manipulated compositional effects. The box set is therefore a technology ideally suited to Mitchell's directorial system. It enables her and her designers both to surround the actors with naturalistic details that enable them to 'simply use the space as their characters logically would', 43 and to create, from the audience's perspective, a frame that converts performers and scenic elements alike into standing-reserve for compositional exploitation.

This enframing capacity of the box set has been doubled by Mitchell and designer Vicki Mortimer's technique of 'split-screen' staging, which they first developed for the two simultaneous locations of James MacMillan's opera Parthenogenesis (ROH Linbury Studio, 2009). Their 2011 production of Thomas Heywood's A Woman Killed With Kindness juxtaposed the homes of two women: Susan Mountford (Sandy McDade) and Anne Frankford (Liz White), in a huge multi-level box set, divided so that the stage right side represented the declining aristocratic pile shared by Susan with her brother Sir Charles Mountford (Leo Bill), and the stage left side, the bustling bourgeois home into which Anne moves following her marriage to John Frankford (Paul Ready) at the play's start. ${ }^{44}$ Five years later, Mitchell and Mortimer took advantage of the greater resources of the Royal Opera House to stage Gaetano Donizetti's Lucia di Lammermoor using six two-sided box sets (a tomb, a dressing room, a hall, a room in Wolf Crag where Lucia's lover Edgardo lives, and Lucia's bedroom and bathroom), juxtaposed in different combinations across the opera's three acts (Image 1).

These two 'split-screen' stagings were closely related but not identical in function. Whereas, in $A$ Woman Killed, when a location was not being used for scripted action it remained sometimes occupied, but rarely conspicuously so, in Lucia the action was deliberately doubled, providing what Mitchell called 'a lot of additional data about what Lucia does while the male characters are singing about her'. ${ }^{5}$ The audience watched, for example, an unwilling Lucia corseted and dressed for her wedding in layers of clothing that Mitchell described as 'quite shocking machines to watch women get into', and then, most strikingly, Mitchell staged Lucia and her maid Alisa's murder of Lucia's husband Arturo on the night of their wedding. ${ }^{46}$ A number of press reviews complained that the effect was distracting, but, as I have argued elsewhere, this distraction (literally, a 'drawing away' of the audience's attention from the narrative as it is usually staged) was evidently a deliberate political 


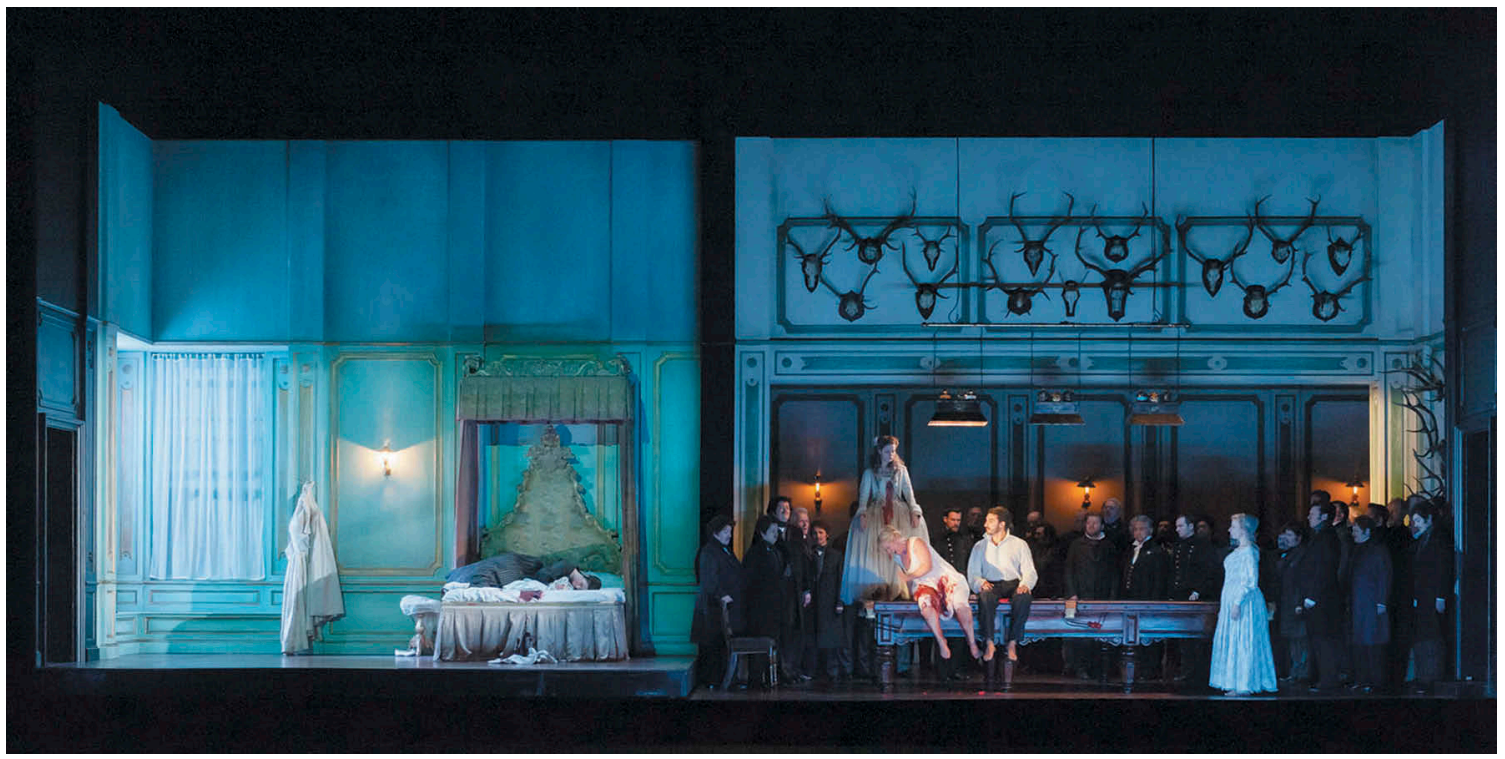

Image 1. Lucia di Lammermoor (dir. Katie Mitchell), design by Vicki Mortimer, Royal Opera House 2016. Photo: Stephen Cummiskey. Copyright: Royal Opera House.

47. See Tom Cornford 'Willful Distraction: Katie Mitchell, Auteurism and the Canon' in The Theatre of Katie Mitchell, ed. Benjamin Fowler, (Abingdon: Routledge, 2019), 72-92 (79).

48. Heidi Hartmann, 'The Unhappy Marriage of Marxism and Feminism: Towards a More Progressive Union', Capital and Class 3 (1979), 1-33 (11).

49. Coppelia Kahn, Man's Estate: Masculine Identity in in Shakespeare (Oakland: University of California Press, 1981), 13 strategy, designed to present the opera's romantic plot in dialectical tension with a narrative about male property. ${ }^{47}$ This narrative focuses on Enrico's need to solve his financial problems by marrying his sister to Arturo and, simultaneously, to maintain control of the lands that his family seized from Edgardo's forebears by ensuring that Edgardo is not allowed to marry into his family.

The theoretical basis for this reading of Lucia is, of course, Heidi Hartmann's much-cited definition of patriarchy as 'a set of relations between men, which have a material base, and which, though hierarchical, establish and create interdependence and solidarity among men that enable them to dominate women'. ${ }^{48}$ The application of this analysis to Lucia is particularly revealing in terms of Hartmann's acknowledgement of the hierarchical but nonetheless interdependent relations that constitute patriarchy. Lucia is, in part, a victim of the direct solidarity between Enrico and Arturo, and Enrico and Raimondo (the tutor who forges a letter from Edgardo leading her to believe him unfaithful), but she is just as much a victim of the feud between Edgardo and Enrico, which is a relation not of solidarity, but of deadly competition. This is because, regardless of the nature of these patriarchal relations, and of whether Lucia is identified in relation to them as a sister, lover, or wife, they always figure her as property. From the outset, Mitchell and Mortimer's staging clearly exposed what Coppélia Kahn called 'the invisible heart' of the patriarchal 'structure' that attempts to convert female bodies into male property, which is the question of whether or not women choose privately to accept its dominance. ${ }^{49}$ At the start, for example, Lucia and Alisa stole clothes from Enrico in which to disguise themselves and escape his house so that Lucia could meet Edgardo. The mise en scene 
also tellingly placed Lucia's bathroom on stage, a private, female space of resort for Lucia, to which men (with the exception of Edgardo after her death) could not gain access.

No such space was offered to Susan or Anne in A Woman Killed. Indeed, Mortimer's set for this production presented the busiest and most public part of both houses: their hallways. The focus, then, was much more squarely on depicting patriarchal relations than on any attempt to resist them. Mitchell and her company used the construction of character biographies to exacerbate the competitive nature of these relations. Charles Mountford's biography, for example, described a failure of masculinity, a man desperate to reassert himself, who had come into his title and land young (following his father's accidental death), and subsequently invested unwisely, sold property, and spent 'lots of money', before being refused military service because of his flat feet and thrown out of his father's club for starting a fight over a card game. This biography established a Mountford who was far too keen to challenge Sir Francis Acton (Nick Fletcher) in the play's first scene with a bet on their relative successes while hunting as a way of earning back some lost reputation. Here was a man trapped by inadequacy, who could not even cope confidently with winning the wager, as he subsequently would. When Acton then suggests that he has won unfairly, Mountford becomes immediately aggressive, triggering a fight in which he accidentally shoots a huntsman, for which he is imprisoned. Mountford's sister Susan is then left isolated within a property that is gradually emptied as her brother falls ever more into debt. Meanwhile, Acton attempts to further ruin Mountford by breaking into his house, where he encounters - and is almost shot by - Susan. Immediately afterwards, Acton pronounces himself in love and asks for Susan's hand in marriage, an offer which would rescue her brother from financial ruin, and one which - inevitably - he forces her to accept.

The other homosocial competition in the play, between John Frankford and Wendoll over John's wife Anne, was also intensified by Mitchell and her company's construction of character biographies. Whereas Acton and Mountford were pitted against each other as examples of upper class masculinity, Wendoll was positioned as a class intruder, who grew up in his mother's parents' pub, and failed the scholarship exam for St Paul's school. His subsequent attempts to join the ranks of the bourgeoisie were entangled with a history of womanising around the edges of the moneyed classes to whom he sold cigars for a living. This biography made Wendoll's seduction of Anne deliberately calculated, and motivated by the combined desires to revenge himself against the class that had rejected him and to possess the society women who would never marry a man with his background. However, whereas Leo Bill's tense and twitchily over-enunciated portrayal of Mountford made transparent the failed masculinity that drove his part of the plot, Sebastian Armesto's Wendoll had no opportunities to communicate either the psychological or class basis for his seduction of his friend's wife and this aspect of the production's politics therefore lay hidden in plain sight. 
This failure of Mitchell's Woman Killed fully to embody the class politics of its analysis of the play-text was ironic given that it chose to articulate its critique of the ways in which women's lives are entangled and stifled by the social relations of patriarchy through the representation of property via the technology of the box set. It does, however, point to a related strength and weakness of this representational strategy. On the one hand, both Lucia and Woman Killed demonstrated effectively that solidarity between men need not look like solidarity in order to prove effective in subjugating women. Patriarchy is formed, they argued, by a range of solidarities, which need not be convivial or even civil, and may even take the form of deadly opposition, provided they agree upon the fundamental question of the gendered division of power. Since the power for which men fought in these productions across and upon women's bodies was only available to them to try to seize from each other as a result of its gendered division, there was nothing any of them could do in its pursuit that would not have constituted an act of solidarity with their opponents from the point of view of the women. By contrast to this compulsory male solidarity, the women were constantly isolated. Lucia could only find privacy in her bathroom, and, although she was supported by her maid, had no other female company. Anne and Susan were likewise alone, their social and domestic lives ordered by the men for whose benefit almost all aspects of their behaviour were constructed. On the other hand, it is telling that whereas both productions were successful in depicting both the oppression of conspicuously privileged women and the competition between men of a similarly elevated social class, neither succeeded in encapsulating oppression or competition between classes. Wendoll and Frankford appeared simply as lover and cuckold, and servants were simply help-meets, there literally - to furnish the scenes and support the narrative development. Property ownership, violence and oppression were therefore conceived, in both of these productions, primarily as consequences of gender. Class relations were either naturalised (servants served) or reduced to individual character traits.

It is important to stress that this shortcoming of these productions did not stem from a failure of analysis on Mitchell's part. On the contrary, her treatment of both texts demonstrated clearly her awareness of the function of class in these narratives. Rather, I propose that the fault lay in the combination of this analysis with the technological apparatus of realism. It uses biography, for example, for psychological ends - conceiving it as a history of individual development which underpins a set of intentions and decisions. The role of biography, in other words, is to support the narrative by stepping in to answer the question of why a character chooses to act as they do. In the cases of Mountford and Enrico, this is significant for an audience, because it is not immediately obvious why they would wish to force their sisters to marry against their will. In the case of Edgardo or Wendoll, however, romantic convention furnishes an answer before the question is asked: they seduce these women because they are in love with them. At this point, the technology of the box set also intervenes to pre-empt inquiry. Just as the camera obscura, in Steadman's description, 'collapses three-dimensional space 
onto the two-dimensional plane' so that 'objects' become 'shapes', so the box set - realistically deployed - collapses the contested dimensions of class and gender relations into the conventional appearances of material culture.

\section{Dramaturgical Apertures: Subjects and Backgrounds in A Dream Play (2005) and 4.48 Psychose (2017)}

50. Sarah Kane, Interview with Dan Rebellato, November 3, 1998, transcript available at https://intranet.royal holloway.ac.uk/dra maandtheatre/docu ments/pdf/ skane1998.pdf (accessed July 31, 2019).

51. Ibid.

52. National Theatre, 'Katie Mitchell on Cleansed', YouTubeVideo, March 7 , 2016, https://www. youtube.com/watch? $\mathrm{v}=5$ LizhtwXP8A (accessed July 31, 2019), 00:05:30.

53. Leah Sidi, 'A Director in Search of a Narrative: RealityTesting in Katie Mitchell's Cleansed', Performance Research 'On Proximity' 22, no. 3 (2017): 49-56 (52).

54. Ibid., 54 .

55. Ibid., 55, 56 .

56. Christina DelgadoGarcia, 'Subversion, Refusal, and Contingency: the Transgression of Liberal-Humanist Subjectivity and Characterization in Sarah Kane's Cleansed, Crave, and 4.48 Psychosis', Modern Drama 55, no. 2 (2012): 230 250 (233).

57. Katie Mitchell, 'Director's Note', National Theatre Programme for A Dream Play (2005).
Mitchell's recent engagement with the work of Sarah Kane, directing Cleansed at the National Theatre in 2016 and 4.48 Psychosis at the Deutsches Schauspielhaus Hamburg in 2017 (referred to here under its German title 4.48 Psychose), has seen her realist agenda encounter an aesthetic form even more resistant to it than Donizetti's bel canto opera or Heywood's verse drama. Kane said that she 'loved the idea' of 'plant[ing] a bomb' in the middle of her play Blasted to 'just blow the whole fucking thing up' partly because blowing up 'a nice little box set in a studio theatre somewhere' was 'what I've always wanted to do'. 50 Likewise, Mitchell's decision to base the structure of Cleansed on Büchner's Woyzeck was a response to 'all this naturalistic rubbish'. ${ }^{51}$ For Mitchell, however, the play's directorial challenge was not primarily the impossibility of its stage directions, but its refusal to conform to realist logic. She decided to address this by treating it as 'surrealism' which meant, for her, placing her actors 'inside a dream landscape', enabling them to commit 'to what they were doing as opposed to going "this doesn't add up; why is my character doing this?" 52

Leah Sidi has critiqued Mitchell's desire for Cleansed to 'add up' as a failure to engage with Kane's formal refusal to constitute Grace as its 'central character', which 'makes it difficult to relegate the strangeness of the play to one mental disturbance'. ${ }^{53}$ She demonstrates how, in Mitchell's production, '[t]he entire play was staged as Grace's nightmare journey through imaginary tortures, occasioned by her grief at the loss of [her brother] Graham, ${ }^{54}$ describing Mitchell's formal intervention as an attempt to make of Kane's 'uniquely un-cohering vision' 'a coherent "whole", 'to introduce stability into a deliberately unstable dramatic universe'. ${ }^{55}$ Whether or not any production can match a vision that is 'uniquely un-cohering', remains, of course, an open question. If, as Cristina Delgado-García has argued, Cleansed seeks fundamentally to destabilize 'liberal-humanist selfhood' by presenting bodies as 'the contingent effect of dynamic processes that repeatedly inform and subject physical matter', then it may be that any staging of it is bound to fail in this respect. ${ }^{56}$ Nonetheless, if Kane's play is constitutively contingent, it is also true that Mitchell's staging of it was unusually definitive.

It is also significant that this was not the first time that Mitchell had deployed such a thoroughly cohering directorial strategy. She began work on her 2005 production of Caryl Churchill's version of Strindberg's A Dream Play by making 'one crucial decision: we would try to make the production as close to a dream as we possibly could and any text which got in the way of that idea would be gently excised'. ${ }^{57}$ 
58. August Strindberg, adapted by Caryl Churchill, A Dream Play (London: Nick Hern Books, 2005), 'Author's Note'.

59. Ibid.

60. Ibid.

61. Mitchell, 'Director's Note'.
The reason for excising Strindberg's text is not immediately clear since it developed from exactly the same premise as Mitchell's, the attempt to represent a dream:

the author has in this dream play sought to imitate the disjointed yet seemingly logical shape of a dream. [...] Time and place do not exist; the imagination spins, weaving new patterns on a flimsy basis of reality: a mixture of memories, experiences, free associations, absurdities and improvisations. The characters split, double, multiply, evaporate, condense, dissolve and merge. ${ }^{58}$

Mitchell's production was, indeed, disjointed, but it would not be true to say that, within it, time and place did not exist. Indeed, the prompt script is careful to note specific locations for all of the scenes in the play, which were represented realistically on stage. Like Strindberg's description of his play's characters, these locations were split, doubled and multiplied in the action, and the scene changes between them were orchestrated to give the impression of either evaporation, condensing, dissolution, or merging. By contrast, the characters did not, as rule, behave in this way. They were, on occasion, doubled or multiplied in the staging (with, for example, the same scene happening simultaneously or sequentially in different areas of the stage), and sometimes carried echoes of each other through the doubling of roles, but as a rule they remained consistent and clearly identified in relation to the facts of a waking world that Mitchell and her company invented.

Mitchell's choice to include action from this world is the key to the crucial difference between her production and Strindberg/Churchill's text. Strindberg asserted in his author's note that 'one consciousness rules' the action, that of the dreamer: 'for him there are no secrets, no inconsistencies, no scruples and no laws', but he does not identify this dreamer with any particular character. By contrast, Mitchell decided that, in order to clarify the idea that 'the audience $[. .$.$] were watching$ a dream', she would create 'the framing device of a dreamer going to sleep at the beginning and waking up at the end' as an aperture through which the audience would view the play. ${ }^{59}$ The dreamer in question was the Officer in Churchill's adaptation, changed by Mitchell to a stockbroker named Alfred Greene (Angus Wright) (see Image 2), with an internal monologue that appeared sporadically in voiceover throughout the production, performed by other members of the cast. 'All the scenes', Mitchell added, 'were angled around this central idea of a dreamer', 60 just as the light that projects an image inside a camera is angled through its aperture.

Mitchell's decision to create this dramaturgical aperture onto Strindberg/Churchill's text emerged, as her programme note explained, from the 'one overriding fact' that she and her company took from their study of dreams through the work of Freud and Jung: 'there is always one dreamer in whose consciousness the action of the dream occurs'. ${ }^{6}$ The company chose the Broker from a shortlist of potential dreamers (which also included Agnes and the Writer) because 'he was the 


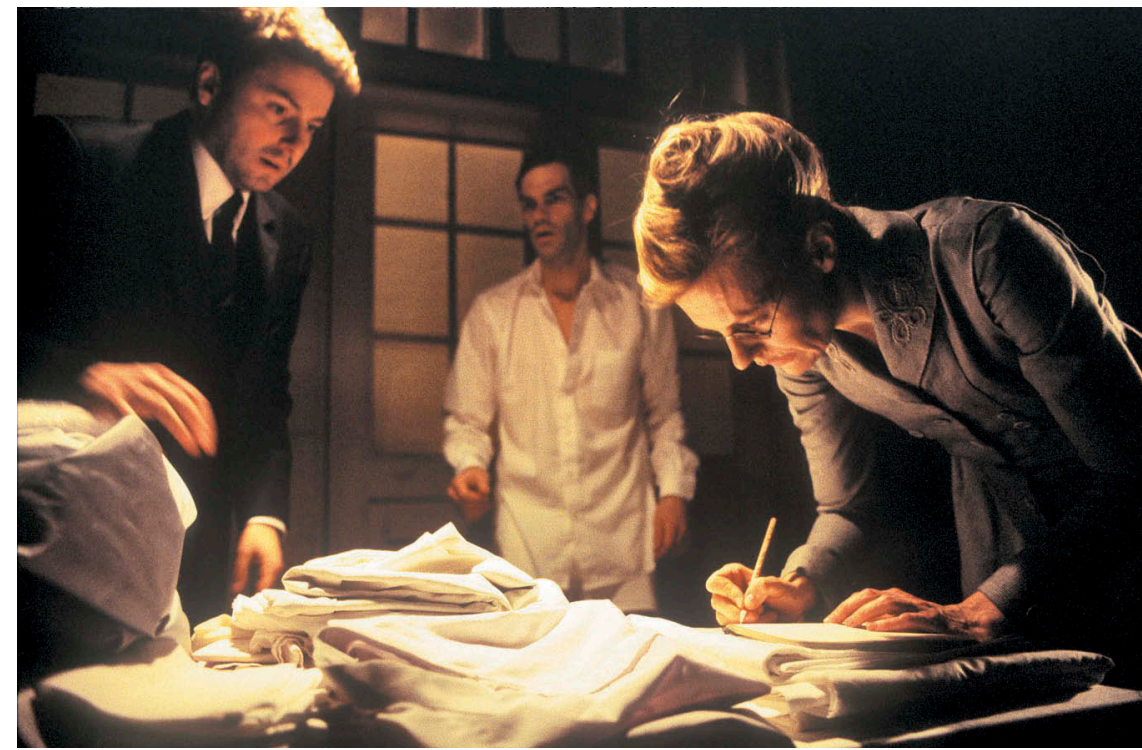

Image 2. Angus Wright as the Broker (centre) with Dominic Rowan as his father and Anastasia Hille as his mother in A Dream Play, Cottesloe Theatre, London, 2005. Photo: Stephen Cummiskey.

62. Ibid

63. Ibid

64. Katie Mitchell, 'Doing the Impossible: Katie Mitchell in Conversation with Dan Rebellato', in Theatre and Adaptation: Return, Rewrite, Repeat, ed. Margherita Laera (London: Bloomsbury, 2014), 213-26 (214).

65. Anna Harpin, Madness, Art and Society: Beyond Illness (Abingdon, Routledge, 2018), 184.

66. Ibid., 185-6. character about whom there was most information and that information coincided closely with aspects of Strindberg's own biography'. ${ }^{62}$ They then combined 'facts in the text' with 'information about Strindberg's life and the details of life in Britain from 1900 to 1950' to create a biography for their dreamer, whose life was historically and geographically relocated in order to bring 'the action closer to today' without making the play's social conventions 'illogical' for its setting. ${ }^{63}$ As a consequence, as Mitchell recalled later, 'we only kept 40 per cent of the original text; 60 per cent was added material based on improvisations around the biography of [the Broker]'. ${ }^{64}$

This decision was particularly effective in capturing the melancholia of Mitchell's chosen subject, marked - as Anna Harpin observes the melancholic is - 'by loss and retrospective gaze'. ${ }^{6}$ Harpin draws upon accounts of pathological time signatures to analyse Marsha Norman's play 'night, Mother as an example of 'temporal warping', created by 'the imprecise dialogue between practical and emotional time signatures' and enabling 'the inhospitality of ordinary time when set against feeling time' for those living with unendurable distress to be exposed. ${ }^{66}$ Mitchell's Broker existed similarly between time signatures, falling asleep at the play's start just as the bell announced the closure of the stock exchange and the suspension of capitalist time, and returning again and again in dream-time to childhood fears and humiliations, to the failure of his parents' marriage and his mother's death, and to his ongoing fear of sexual inadequacy.

Mitchell's directorial intervention to create this tension between time signatures by including both in her production rather than adhering to the dreamscape of the text pulled in two directions. On the one hand, it offered 
the opportunity to explore the difference between the times that exist, as it were, either side of the shutter. The compression of time within the capitalist structure of the working day briefly glimpsed at the play's start, with activities squeezed into the shortest possible time-frames, could not - it seemed - be more different to the apparently limitless capacity of dreams repeatedly to revisit and reiterate experiences long past. On the other hand, the provision of a referent in waking reality for each dreamed experience harnessed the play, in the same way that Sidi observed of Cleansed, to the coherent and selfconsistent psychology of an emasculated, humiliated man, haunted by the losses of his childhood, and apparently doomed to replay the emotional failures of his parents in his own life. As a result - and in spite of its gestures in this direction - the production did not, ultimately, articulate a temporal crisis of modernity, in which there is literally no time for the subject to live with his past because his time has been appropriated by capital in order to sustain itself as a process, whereby, as Marx observed, value must be kept continually in motion. Instead, Mitchell's production focused its diagnostic aperture on the subject as cause, framing his melancholia within a set of personal circumstances rather than social relations, and thereby forestalling any attempt to read his melancholia as an attempt to escape from the temporality of capital.

Twelve years later, Mitchell chose, once again, to depict a mind-space cut loose from the clock-time of capital by presenting the speaker of Sarah Kane's play 4.48 Psychosis as a single subject, played by Julia Wieninger, in Mitchell's German-language production (translated by Durs Grünbein) at the Deutsches Schauspielhaus in Hamburg (see Image 3). For the most part, Kane's play does not even adhere to the linearity of dialogue, let alone the

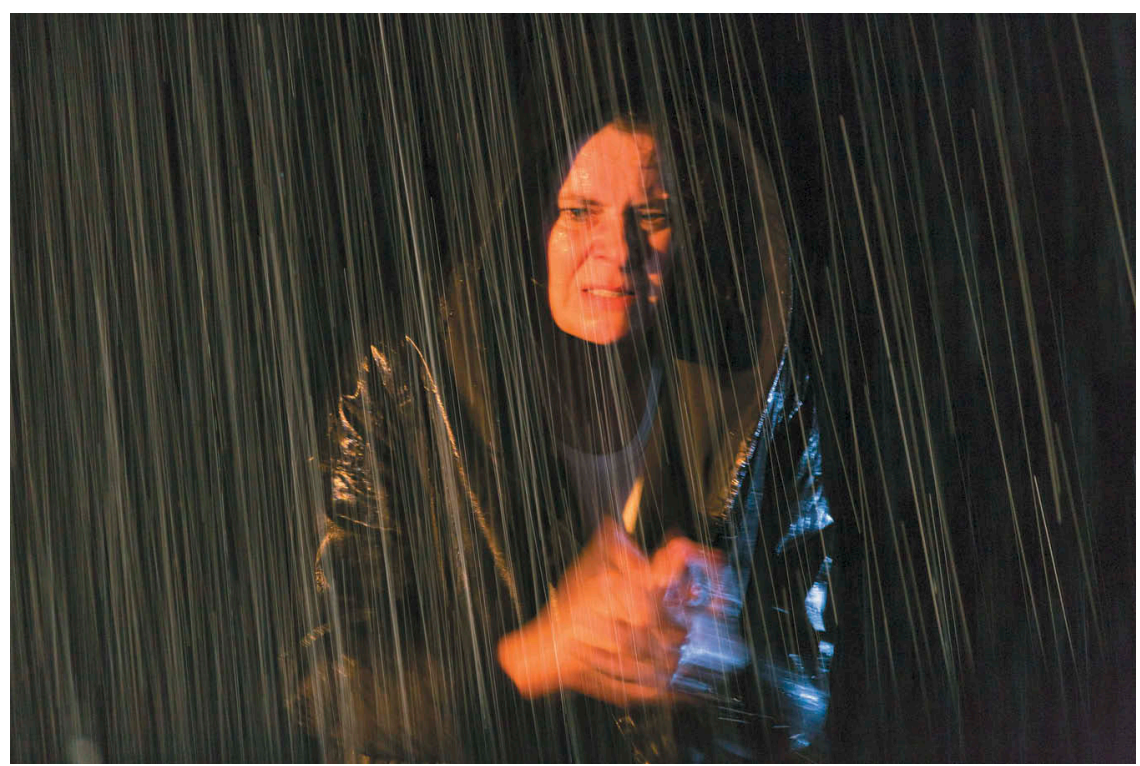

Image 3. Julia Wieninger in 4.48 Psychose, design by Alex Eales, Deutsches Schauspielhaus Hamburg 2017. Photo: Stephen Cummiskey. 
wider time-frames of realism. The text is a form of reiterative montage, with no obvious over-arching narrative development or centre, and thus constitutively both allusive and elusive. Mitchell's response was to focus her production on a figure decentred in her own life, caught among voices that threatened her self-stability, among echoing memories of love, loss, and failed treatments. Wieninger's protagonist therefore performed the entire play as a monologue, occasionally intercut with remembered voices, mostly while walking (on a travellator that was invisible to the audience) through contemporary Hamburg, which was created around her by Donato Wharton's sound design and Jack Knowles' sparing lighting. She passed cafés and restaurants, was almost run over by a car, walked through the central railway station, visited the docks where she began to wade into the water, made unanswered phone calls, caught a bus, walked in silence in the pouring rain, passed through a tunnel under the river, and finally crouched on a railway line to await the train that would kill her. She was, in short, set loose in a world that seemed casually and implacably hostile, and from which she was finally, violently released by death.

Sidi's critique of Mitchell's introduction of 'stability into [the] deliberately unstable dramatic universe' of Cleansed can, of course, be applied with equal justification to this rendition of 4.48 . However, an alternative interpretation of the decision to generate a realist, solo dramaturgy for Kane's play that narrows towards the character's death is suggested by an echo of Kane's text in her chosen ending. 'I am charging towards my death', the text says, 'At 4.48/when depression visits/I shall hang myself/to the sound of my lover's breathing'. In Mitchell's production, however, it was death that was charging towards the speaker, in the form of an express train - the 4.48 to oblivion, perhaps. Seen in this light, Mitchell's ending can be read as a critique of what Jonathan Crary analyses as the late twentieth-century's 'fulfilment and consolidation of systemic possibilities that were incipient in Arkwright's mills and which became only partially realized with the transportation and communica-

67. Jonathan Crary, 24/7: Late Capitalism and the Ends of Sleep (London: Verso, 2014), 74 . tion networks of the nineteenth century ${ }^{67}$ Those networks were made possible not only by the steam engines that powered ships and trains, but by the previously existing social relations of colonial expropriation, many of which were materialised in the form, for example, of the railway lines and timetables that scheduled the delivery of extracted resources to the metropolitan centres of colonialism, such as the port of Hamburg. Situating Wieninger's protagonist in Hamburg - and specifically in both a railway station and a port - before she is obliterated by a train, drew attention both to the refusal of the depressed person to obey capitalist time and to the disposability of those mentally ill people who cannot or will not govern themselves as neoliberal regimes expect. Placing that protagonist on a treadmill, of course, and having her leave it to climb onto the tracks in order to commit suicide, potentially heightened that critique, but Mitchell chose, instead - by using a brightly illuminated frame around the production and keeping all other lights very low - to deepen the gloom that surrounded Wieninger and conceal the central technological apparatus upon which her concept depended. Furthermore, by ascribing the plural and 
68. See Cornford, 'Willful Distraction', 82-4. unidentified voices of Kane's text to a single and seemingly psychologically coherent character, Mitchell submerged the psycho-geographical potential of her production and brought to the surface, instead, a portrait of individual distress occasioned, seemingly, by lost love and inadequately treated by a pharmaceutically oriented healthcare system. Thus, Mitchell substantially forestalled a political critique that lay both immanent within and concealed by the technological apparatus of her production.

Thus, the technologies deployed in these two productions framed the central subjects around which they sought to cohere as individual entities, shaped by biographical narratives, rather than considering subjectivity primarily as a site of social and political relation. In both cases, this was a direct consequence of the dramaturgical system, employed by Mitchell, of focusing her play-texts through the aperture of a single subject, which inevitably posits psychological experience as an ultimate reality, a figure to which social relations are merely a ground. Elsewhere in Mitchell's work, most notably in Fräulein Julie (Schaubühne, 2011), she has used the position of a single subject to expose gender and class relations. ${ }^{68}$ In both $A$ Dream Play and 4.48 , however, the stage technologies of lighting, sound, and trucking and flying scenery on the one hand, and a travellator on the other, created mobile backdrops that enabled their protagonists to move through their narratives while remaining, both literally and figuratively, central and in focus. In order to achieve this effect, these technologies were, in both cases, necessarily occluded and defocused, like the gloomy background of a portrait designed to offset the intricate detail in which it presents its subject. As a result, in both cases, social relations were reduced to a backdrop for the representation of psychological subjectivity in ways that were markedly distinct from the relational and blurred subjectivities of their playtexts. We turn now, however, to a set of productions where technology could hardly be less occluded, in which Mitchell and her collaborators have developed the genre that has come to be called 'live cinema'.

\section{'The Language of the Machine': The Technology of Mitchell's 'Live Cinema'}

The imagined train that ran down Wieninger's protagonist in 4.48 carried echoes of the set, by Lizzie Clachan, for another of Mitchell's explorations of female suicide, The Forbidden Zone (text by Duncan Macmillan, Salzburg Festival, Schaubühne and Barbican, 2016). A series of interior period sets upstage were repeatedly obscured by a full-size replica of a 1940s Chicago subway carriage that was trucked back and forth across the downstage area throughout the production (see Image 4). The Forbidden Zone culminated in the deaths of two scientists. First, the chemist Clara Haber (née Immerwahr, 1870-1915), played by Ruth Marie Kröger, who shot herself in an act of protest at a party to celebrate the successful development of chlorine gas by her husband Fritz Haber. Second, her granddaughter Claire 


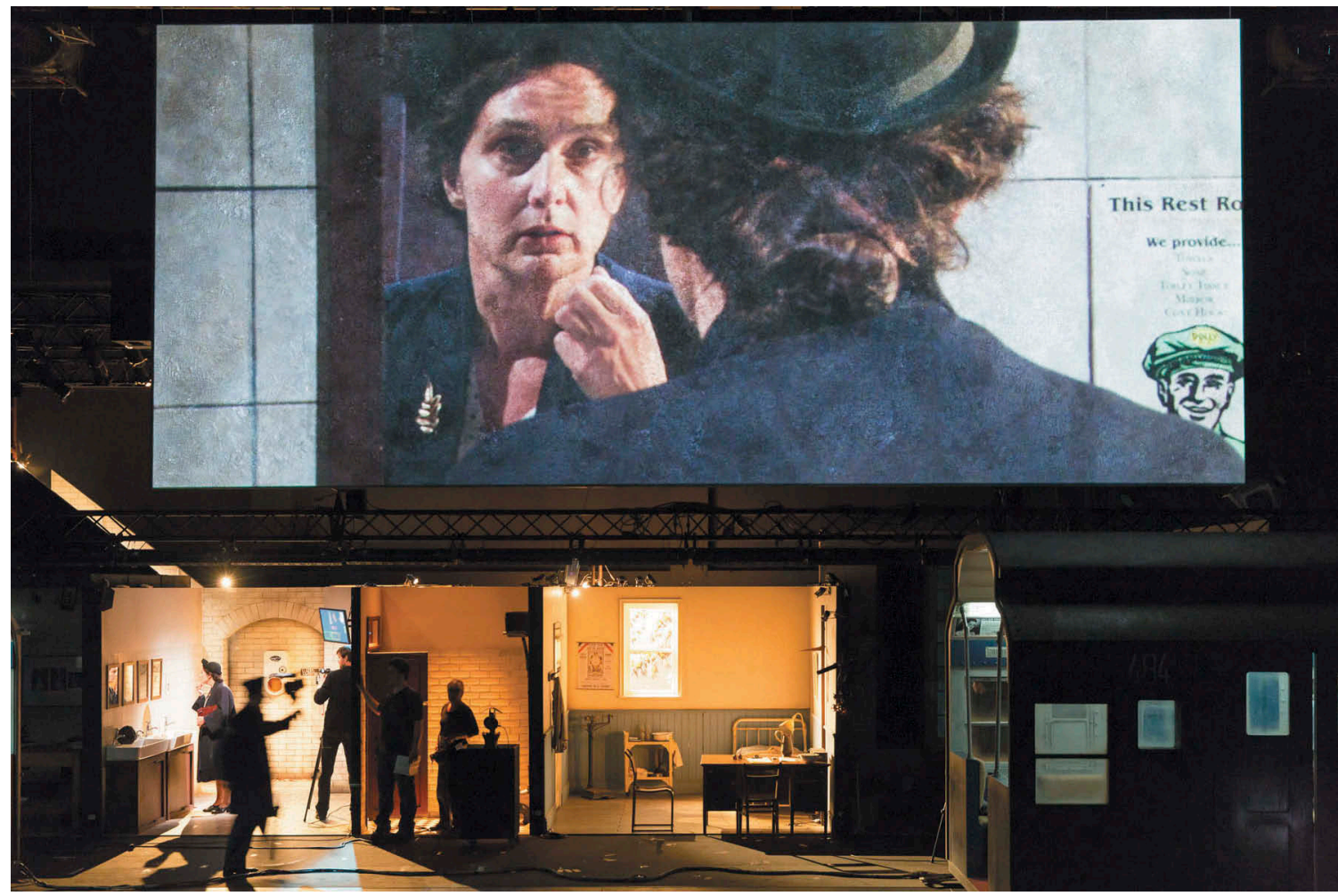

Image 4. Kate Duchêne on the screen over the stage, The Forbidden Zone, design by Lizzie Clachan, Schaubühne, Berlin, 2016. Photo: Stephen Cummiskey.

69. Salzburg Festival, 'The Forbidden Zone 2014', YouTube-Video, June 18,2014 https://www.you tube.com/watch?v= tRzphUKspwI (accessed April 30, 2019), 00:02:18, 00:01:47, 00:01:01

70. 59 Productions, 'Forbidden Zone - The Making of a Live Cinema Show', Video, July 23, 2014 https://vimeo.com/ 101517150 (accessed April 30, 2019), 00:02:35
Haber (1928-49), played by Jenny König, who took a lethal dose of cyanide when she discovered that her research into antidotes for poison gas was to be passed over for funding.

The narrative role of this carriage was to deliver Claire to the location of her suicide, a journey that was also a chase, as a concerned colleague (Kate Duchêne) tried to reach her in time to prevent her from taking her own life. Scenographically, however, the carriage also served to foreground the 'enormously complex procedure' governing what Mitchell described as the 'most ambitious' of her live cinema productions to date, with its 'four different narratives in two time-zones' ${ }^{69}$ Mitchell's video director, Leo Warner, described the train as a kind of totem of the production's aim for the highest possible cinema production values:

... because we're able to put cameras inside and outside that train, we can then apply, for example, elaborate lighting effects that really do create the convincing effect that those performers are travelling at high speed through a subway tunnel. There's very little suspension of disbelief required when you look at the cinematic output $[\ldots] .^{70}$

While the train stood, then, in the narrative, for the ineluctable and violent historical progress of capitalist patriarchy, for the production's 
71. Leo Warner, 'Stages and Screens: Katie Mitchell's Theatre Aesthetics, Janis Jefferies in Conversation with Leo Warner', in The Theatre of Katie Mitchell, ed. Benjamin Fowler, (Abingdon: Routledge, 2019), 93-120 (115).

72. Donato Wharton, Interview with the author, October 2016. makers, it seems to have represented the ineluctable logic of the technology they had created and were bound to serve. As Warner put it: ' $[\mathrm{t}]$ he machine exists and people get supplemented in and out and it continues to evolve'. ${ }^{71}$ Mitchell's regular sound designer, Donato Wharton, confirmed that 'the word "machine"' is 'used often' by Mitchell's live cinema teams, because each show 'really is like a jumbo! They're so complex'. ${ }^{72}$ Warner described, for example, the 'extraordinary level of documentation' the process requires:

every single performer and every single camera operator has a kind of bible of notes which tells them exactly what they should be doing at any given moment. It's very very hard to keep up the momentum of going from shot to shot for an entire hour-long piece, so the process of actually putting the whole thing together has a real edge of danger to it because at any moment literally anything can go wrong.

Wharton told me that this process is so demanding that it has to function systemically, so that it can exceed the direct agency of its makers. It depends, he said, upon 'building a system as you go along and managing it and building the logistics of it', so that 'the shows develop such a strong inner logic that, for me, the choices start making themselves'. Not only are company members required to create bibles (see Image 5 ), they must create bibles that can learn to write themselves.

The technological condition of live cinema production, then, is one of unencompassable complexity, in which human beings become enframed by technology so that we can no longer manage the inter-relation of

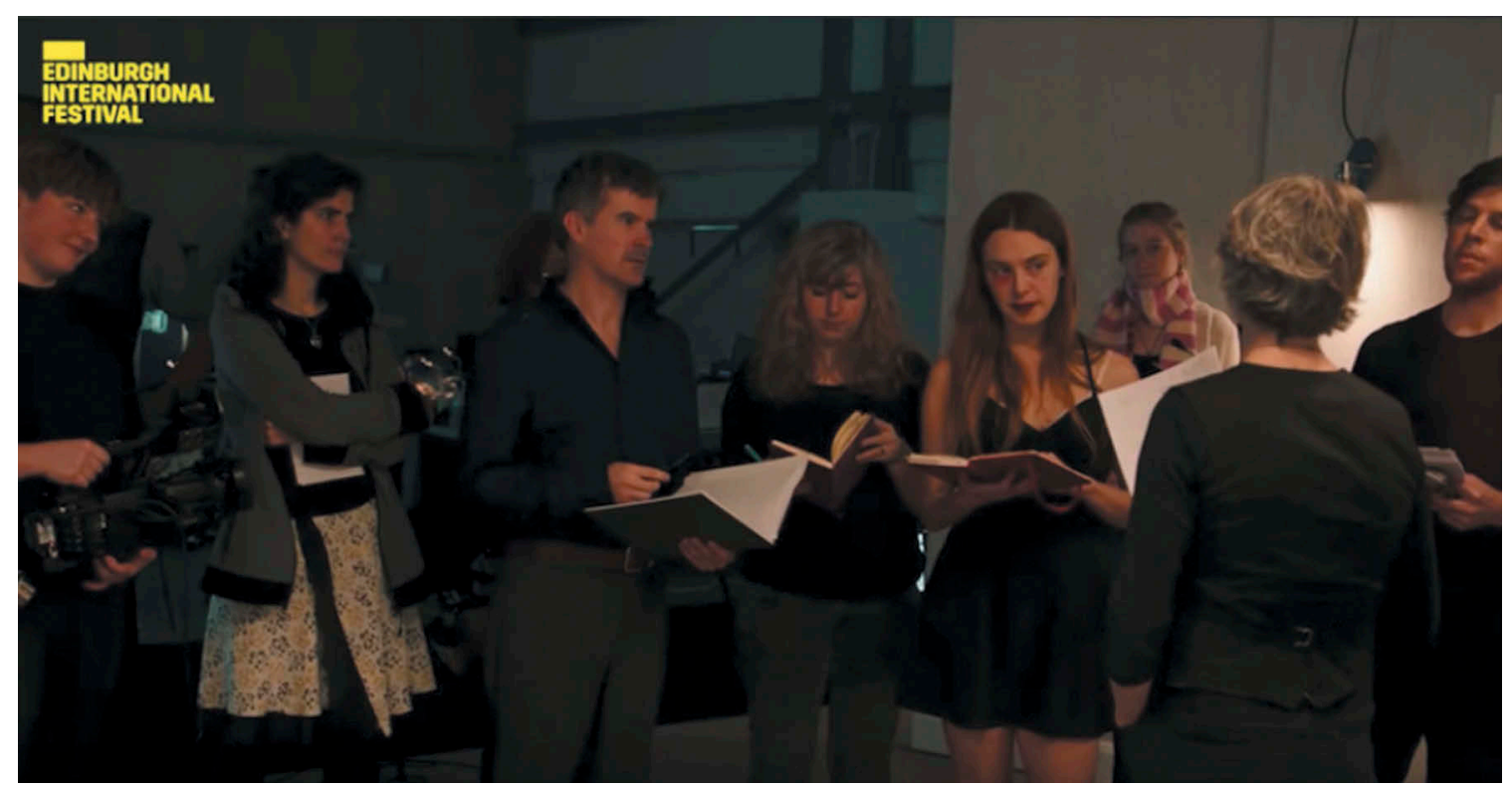

Image 5. Actors and crew with 'bibles', screen grab from Edinburgh International Festival, 'Katie Mitchell on La Maladie de la Mort, 2018 International Festival', YouTube-Video, 14 March 2018 https://www.youtube.com/watch? $\mathrm{v}=\mathrm{CpSeZbjlofc}$ (accessed on 17 February 2020), 00:00:37. 
73. Jean-Luc Nancy, trans. Charlotte Mandell, After Fukushima: The Equivalence of Catastrophes (New York: Fordham University Press, 2015), 25.

74. Ibid., 30 .

75. Ibid., 31 .

76. Ibid., 36 .

77. Ibid

78. Warner, 'Stages and Screens: Katie Mitchell's Theatre Aesthetics', 98-9.

79. Ibid., 96.

80. Ibid., 97.

81. Ibid., 99-100. causes in our productive activities, like Heidegger's silversmith, but are overwhelmed by and subjected to assemblages of our own creation. This condition echoes Jean-Luc Nancy's account of contemporary civilisation, in which 'it seems impossible to envisage anything but everincreasing forms of interdependence, processes becoming ever more intricate and complex'. ${ }^{73}$ Nancy is considering, here, the 'powerfully exemplary event' of the 2011 nuclear disaster in Fukushima, which he attributes to 'the close and brutal connections between a seismic quake [the Tōhoku earthquake of 11 March], a dense population, and a nuclear installation (under inadequate management)'. ${ }^{74}$ This event exemplifies, for Nancy, the exponential growth of humanity's capacity to transform nature to the extent that 'we can no longer speak' of it but must, instead, address a continuously expanding 'civilizational catastrophe' which is 'no longer just a question of human decision: this decision becomes such that what it decides goes beyond anything calculable as the effects of some decision'. The political stakes, for Nancy, of this situation are therefore to be found in the challenge posed by 'the interdependent totality of our technologized world - which is specifically a world of human creation and at the same time a world to which virtually all beings are entirely subjected'. ${ }^{75}$ This situation represents a fundamental, ontological challenge for human action because, under these circumstances, ' $[\mathrm{t}]$ echnology is not an assembly of functioning means; it is the mode of our existence'. ${ }^{76}$ Within this mode of existence, Nancy argues '[e]verything becomes the end and the means of everything' 77

Viewed from this perspective, the technology of live cinema is not simply a means of representation, but becomes an end in itself, for which, conversely, visual and dramatic material supplies a means. The technology necessitates almost constant activity, as Warner notes: 'it has to be incredibly efficient; we really can't afford to throw away more than a couple of minutes a day, because you might make one shot in that time, but in a show which is built of four, five, six hundred shots, that's all you can do, just keep making the individual components'. ${ }^{78}$ As Mitchell and Warner's collaborations have developed, the production values of these components have exponentially increased and so has their consistency, so that it is now fully justified to refer to the 'cinematic output' of the process, which is seamlessly continuous. This was not always the case. Warner describes his first collaboration with Mitchell (Waves, 2006) as a series of 'glimpses and vignettes' (see Image 6), ${ }^{79}$ devised in the rehearsal room and then strung together during technical rehearsals in the theatre, whereas now their productions require 'essentially a full technical rehearsal throughout the rehearsal period" ${ }^{80}$ : 'we try and replicate the machine as thoroughly as possible in the rehearsal room'. ${ }^{81}$ The demands of the technology, in other words, have expanded to such an extent that they dominate the entirety of a production's rehearsal: they are, to borrow from Nancy, 'the end and the means of everything'.

The consequence of this technological expansion can be seen by returning to earlier productions, which were usually described as 


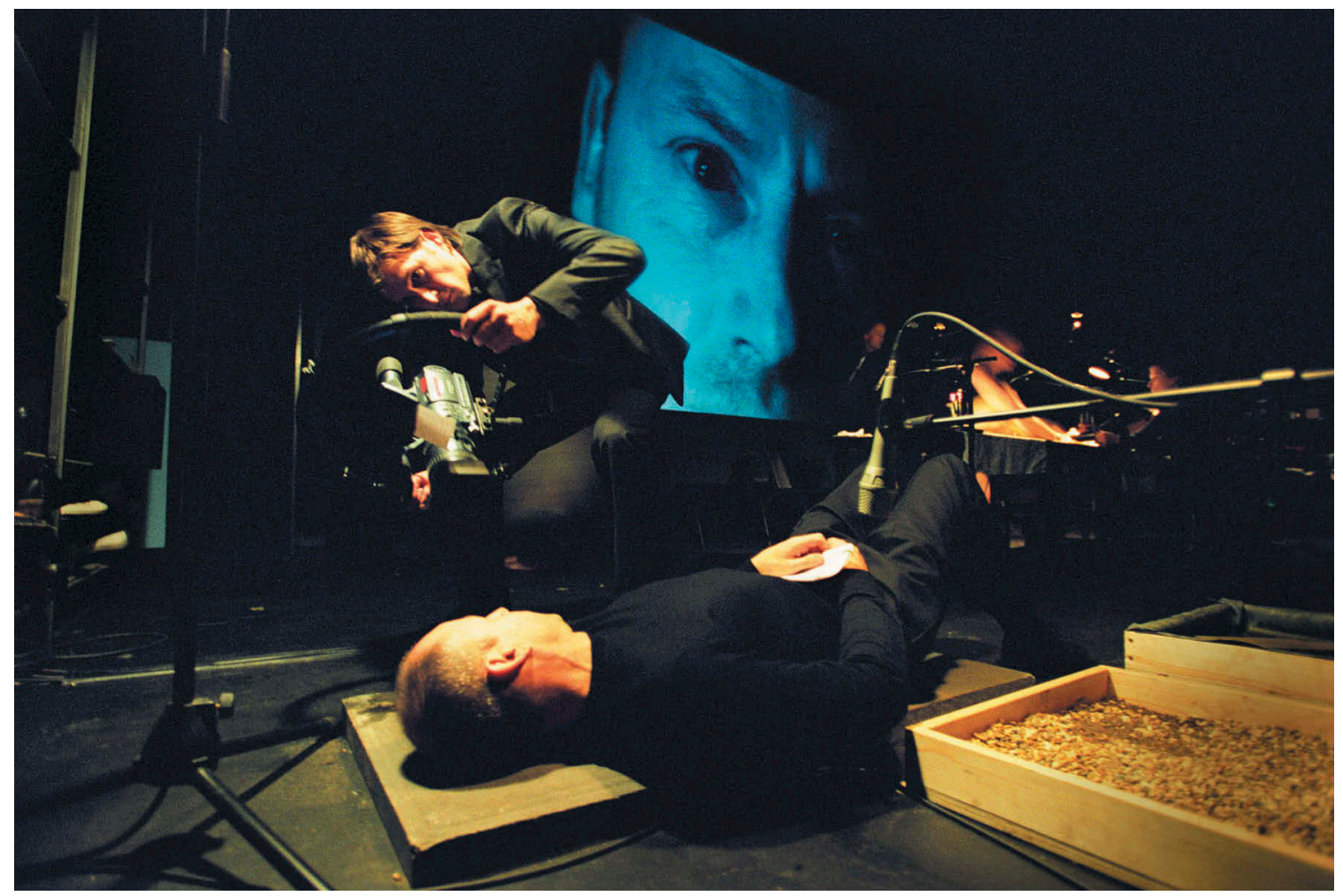

Image 6. Jonah Russell shooting Sean Jackson in Waves, design by Vicki Mortimer, Cottlesloe Theatre, London, 2006. Photo: Stephen Cummiskey.

82. Ibid., 112 .

83. Ibid., 113. 'multimedia', rather than 'live cinema'. Warner notes that, whatever their generic title, 'the choreography of the stage' in these productions has always been 'largely dictated by camera cable management', but the exposure of that process to the audience has altered substantially. Warner recalls a 'brilliant sequence' in Waves, after the cables from 'two actors who were operating cameras' became entangled as a result of the performers 'sort of leap-frogging each other' in order to shoot the action. At the end, the actors 'just had to walk round and round and round each other and then separate and, if they get the number of turns right, the cables then peel off in the middle and you carry on'. ${ }^{82}$ This kind of logistical choreography remains characteristic of these productions, but at this moment in Waves, as Warner noted, there was 'nothing else to look at', whereas the huge stage used for The Forbidden Zone, with its four interior sets (which were often partially obscured by the train carriage), and its continuous cinematic output, ensured that logistics were never foregrounded in its staging. ${ }^{83}$

A year after Waves, Mitchell and Warner created a multimedia production of Attempts on her Life in the Lyttleton Theatre. Waves pursued life in closeup: the huge majority of its shots showed only one or two faces and many captured smaller details: eyes, hands, and feet. Attempts, by contrast, framed its performer-technicians as subjects of the dictates of a vast and inscrutable 
84. Liz Tomlin,

'Citational Theory in

Practice:

A Performance

Analysis of

Characterisation and

Identity in Katie

Mitchell's Staging of

Martin Crimp's

Texts', Contemporary

Theatre Review, 24,

no. 3 (2014): $373-7$ (374).

85. Warner, 'Stages and Screens: Katie

Mitchell's Theatre

Aesthetics', 100-1. representational system. The text's scenarios were instigated by a series of sirens, forcing the performers to improvise their way into them, and their colleagues to rush around and set up the necessary equipment to film them. Each of these 'attempts' was projected live onto a huge screen above the stage and drew on a series of recognisable media tropes: a police drama rubbed shoulders with a rock video, a chat show, a press conference and a parody of Newsnight Review. Finally, the scenarios complete, the cast stood apprehensively in a line downstage and were lowered beneath the floor and out of sight. This staging was underpinned by a rehearsal process in which, as Liz Tomlin has observed, Mitchell's company 'decided to establish their own given circumstances based around a live TV show' in which they were 'given a topic around which they would be required to improvise live', and 'developed detailed backstories for their own characters which could naturalistically justify speeches they had been allocated from Crimp's text'. 84

Thus, whether Mitchell was constructing a fictional frame that could contain all aspects of her actors' on-stage activity (both speaking and focusing a camera or holding a boom), or simply allowing their adaptation to the logistical demands of her technology to be prominently visible, these early experiments in this form of multimedia production made explicit the tensions and connections between what Warner calls 'the language of the machine' and the material it sought to represent. ${ }^{85}$ In Waves, the struggle to capture and articulate self and memory was embodied by the performers' negotiations with the production's technology; in Attempts, the text's emphasis on the constant mediation of experience by the regimes of what Jean Baudrillard famously called 'hyperreality' was embodied by a group of people forced to communicate through the reproduction of iterable forms of mass media communication. Like all entanglements, these complications of ends and means depended upon interstices; Mitchell drew them out through her management of the gaps in her technology. By 2014, however, the technology had expanded to such an extent (and Mitchell, Warner and their teams had become so adept at working within it), that the gaps had closed. Nowhere in The Forbidden Zone was the drive of the technology to make the connections between Claire and Clara Haber seamlessly and causatively linear exposed or complicated by the production. Patriarchal war-mongering proceeded remorselessly in this narrative like a train through history, wrecking the lives of the women who were ultimately undifferentiated in its wreckage. If this technology is the mode of our existence, it tacitly proposed, then we're already dead and we always were. The Forbidden Zone thus presented a deterministic vision in which, instead of living in tension with our enframing by an increasingly technological mode of existence, human beings have already been subjected to its will.

\section{Conclusion}

As the range of examples here has shown, Mitchell is a director whose work is unique in the multiple ways in which it has been explicitly imbricated with the technologies of theatrical realism. These 
86. Dennis Kennedy, 'The Director, the Spectator and the Eiffel Tower', Theatre Research International 30 , no.l (2005): 36-48 (44). technologies represent a particular aspect of what Dennis Kennedy has called 'the base on which the superstructure of directing must operate', a nexus of 'trade issues like systems of finance, theatre organization, actor training and unionization'. ${ }^{86}$ They do not, of course operate independently of this 'base' - indeed, in Heidegger's formulation, they all belong at once to each other - but my concern here is to demonstrate their relative independence from the agency of an artist such as Mitchell, who is, by contrast, fundamentally dependent upon them.

The examples gathered here have all demonstrated, furthermore, that the technologies of the realist theatre generate representations that are politically valent. In chemistry, the valency of an element is its power to combine with other elements, expressed by the number of electrons available in the outermost shell of its atoms. In 1897, Charles Sanders Peirce used this idea metaphorically in his development of the grammatical concept of valency, which is the number of arguments controlled by a predicate: the number of expressions, in other words, that complete its meaning. In the context of culture, we could consider valency as the capacity of a representation to bond, politically, with others, and thereby to facilitate the co-constitution of representations that together form an ideological matrix. As this essay has repeatedly demonstrated, this valency is immanent in technology, which can function independently of - and even enframe - the will of the artist who seeks to direct it to their ends.

This is the basis of the systemic resistance of the contemporary realist theatre to critical politics and radical action. The lesson of this essay's analysis of Katie Mitchell's project, therefore, is that 'the director's craft' alone is not enough. The promise of craft to trainee directors is partly the allure of mastering a complex technological configuration; the reality of directing, however, is that the achievement of such mastery always risks being - to evoke Audre Lorde - the means by which the theatre's technologies master you. In this sense, any politically critical theatrical endeavour must begin from the understanding that the theatre's technologies are - in themselves - conduits of hegemonic power; such an endeavour can therefore only take hold if that technological configuration is radically dismantled. 